\title{
The Evaluation of Public Policies from the Perspective of the Agenda 21 of Culture: a Case Study
}

\section{María Aracely Mendívil-Portillo ${ }^{1}$, Luz Cecilia Gálvez-Bon ${ }^{1}$, Juan Pedro Ibarra-Michel ${ }^{1}$, José Guadalupe Soto-Karass ${ }^{1}$}

\author{
${ }^{1}$ Universidad de Occidente \\ 169 Gral. Gabriel Leyva Avenue, Centro, Los Mochis, Sinaloa, 81200, México
}

DOI: $10.22178 /$ pos.25-6

JEL Classification: Z18

Received 16.07.2017

Accepted 10.08.2017

Published online 16.08.2017

Corresponding Author:

Juan Pedro Ibarra Michel

juanpedroibarra.udo@gmail.com

(c) 2017 The Authors. This

article is licensed under a

Creative Commons Attribution

4.0 License @ @

\begin{abstract}
This research shows the results of the implementation of a public cultural policy at the municipal level and has as a main objective to evaluate, from the perspective of the agenda 21 of culture, the program "Art for social development" by the Municipal Institute of Art and Culture developed in a secondary-level boarding school located at the Topolobampo community, in the municipality of Ahome, Mexico. A QUAN-QUAL methodology was used with instruments like questionnaires applied to the young participants and interviews with the workshop facilitators and administrative staff. Guitar, painting and theatre workshops were given, through which the development of new artistic expression skills was achieved, as well as contributing to the strengthening of social behaviors such as tolerance, patience and interpersonal communication, among others. It was found the constant need of having permanent programs of integral training, both in the field of artistic training and socio-emotional, giving priority to groups at risk, such as students of the boarding school that mostly come from families of scarce resources, some of the low performance academic and aggressive behavior. The conclusion is that public policies are required to promote greater articulation of education and culture in order to have a stronger impact on the social and cultural inclusion of young people.
\end{abstract}

Keywords: culture; public policies.

\section{INTRODUCTION}

The complexity of the analysis of the social impact that programs related to culture have in society goes hand in hand with the need to have mechanisms and instruments for the evaluation of cultural policies and programs relevant to the different fields of application: local, state and national levels.

The elaboration and design of public policies on culture face the same obstacles that the concept of culture has, being mainly the ambiguity of the term and the multiple interpretations that has been done of it that demands a theoretical methodological position for the analyst of the cultural phenomenon, as it is for the decision makers in the public sector, involved in the design, implementation and evaluation of public policies.
In the discursive review of the governments, the issue of social impact is a constant that seeks to justify the relevance of a public policy, is the most arduous and persistent argument when it comes to raising cultural programs and their potential benefits, that in very few occasions, evidence of social transformation among citizens is evident, but the lack of evaluation mechanisms and instruments, and particularly a culture of evaluation in all actors involved in cultural policy makers, program managers, artists, facilitators, and others, it does not allow to be certain of the achievements or at least to know what it was that really happened with the participants.

An effort made by organized civil society is constituted by the work of United Cities and Local Governments (UCLG), crystallizing in 2004 the 
document "Agenda 21 of Culture"1, with the purpose of guiding public policies of culture and contributing to the cultural development of humanity. The proposal establishes the relationship between culture and sustainable development, embodied in the Declaration "Culture is the fourth pillar of sustainable development" [20]. This organization, whose headquarters are in Barcelona, later elaborated the document "Culture 21 Actions" in 2015, which aims to be a selfassessment guide that establishes guidelines for evaluating, designing and implementing cultural policies that contribute to sustainable development in the field local.

Recently, the state government of Sinaloa has been incorporated in the 2015-2016 program, promoted by UCLG, "Cultura 21 Acciones", which provides guidance to cities interested in evaluating, designing and implementing cultural policies that contribute to sustainable development. It is in this context that it was considered pertinent to retake some "commitments" or axes of analysis that arises the agenda 21 of culture: cultural rights, culture and education and culture, equity and social inclusion.

In the State of Sinaloa, the planning and implementation of cultural policies and programs fall mainly in the Sinaloa Institute of Culture (ISIC ${ }^{2}$ ). With more than 40 years of operation, this unit has recognized the lack of information systems and evaluation instruments for its cultural policies and programs that allow the beneficiaries to know the results, as well as the performance of government management and agencies and Actors. Efforts in this regard have mainly been to count the number of attendees to cultural events.

At the level of the municipalities of the state of Sinaloa, the problem is similar, information on the results of cultural programs is minimal or null and specifically in the municipality of Ahome, where this research was developed, there is little systematized information on the planning, development and evaluation of the cultural programs operated from the local government. The Municipal Institute of Art and Culture (IMAC) is the municipal body that has had the

1 Document approved on May 8, 2004 at the IV Forum of local authorities for the social inclusion of Porto Alegre within the framework of the Universal Forum of Cultures Barcelona 2004 (edited in 2008).

${ }^{2}$ Instituto Sinaloense de Cultura (in Spanish). responsibility in the last decade to design and operate cultural programs aimed at the various sectors of society.

For this reason, it was considered pertinent to evaluate a cultural program in a locality of the State of Sinaloa and of the municipality of Ahome, that serves as an exploratory study for the design of evaluation instruments with the perspective of the agenda 21, that contemplates some of the dimensions and actions considered by this agenda.

The specific objective of the research is to evaluate from the perspective of agenda 21, the cultural program "Art for social development" implemented by the Municipal Institute of Art and Culture (IMAC) belonging to the municipality of Ahome in the secondary school No 9 of the Topolobampo community. Likewise, this study reviewed national and international benchmarks in the evaluation of cultural policies, plans and programs.

It was considered important to evaluate public policies, through the monitoring of government actions at the local level, and specifically at the syndicate level, to emphasize the importance of the analysis as a permanent tool that contributes to improving the formulation of public policies, strengthen local cultural information systems and generate knowledge in the field of cultural management and cultural policies.

\section{METHODOLOGY}

This research was addressed with a mixed methodological approach, that is, from a qualitative and quantitative perspective.

As a unit of analysis, a cultural program developed from February to May of 2016 was analyzed at the Topolobampo branch of the municipality of Ahome in order to know the results and the specific development of its implementation from the perspective of different agents or participants such as the cultural managers themselves, project beneficiaries/participants and workshop instructors.

The cultural program evaluated in this research, was designed by the Municipal Institute of Art and Culture, is called "Art for Social Development"; was developed in Technical Secondary School No 9 of the Port of Topolobampo, in the municipality of Ahome. 
This program included three artistic workshops: theatre, painting and guitar, which were given to young inmates of the educational institution that mostly come from rural communities of northern Sinaloa.

A total of 48 questionnaires were applied to all students/beneficiaries of the cultural program and continuous visits were made to the secondary school to observe the local conditions in terms of infrastructure, proportion of work materials, as well as the behavior of participants and instructors during the development of the workshops.

Among the sources of information were the revision of the Municipal Development Plan of Ahome, the annual reports of the municipal government, the conduction of 6 semi-structured interviews that included the person responsible for the implementation of the program in the IMAC, the three instructors of the Cultural workshops and two members of the administrative staff of Topolobampo secondary school where the cultural program was developed.

\section{The public policies and the cultural policies}

One of the most important tasks of governments is the design, management, implementation and evaluation of public policies. However, most studies carried out in public policies have been focused on the phases of policy and program formulation, leaving in most cases one of the phases of great importance, such as the evaluation phase. As mentioned by C. Salazar Vargas [17], evaluation is indispensable for the analysis of public policies, the evaluation tries to explain why the facts were given in this or that sense.

Among the main experts is P. Muller [11], who considers public policy as a process of social mediation, insofar as the purpose of each public policy is to take care of the mismatches that may occur between a sector and other sectors, or even between a sector and global society.

In contrast, R. Velásquez Gavilanes [22] considers that a public policy is the process integrating decisions, actions, inactions, agreements and instruments, advanced by public authorities with the eventual participation of individuals, and aimed at solving or preventing a defined situation as problematic. Public policy is part of an environment from which it is nourished and which it intends to modify or maintain.
A. Vargas Velasquez [21] mentions that a public policy is not an isolated decision but a set of positions that involve one or more state institutions. But it also means the materialization of decisions taken in terms of actions that produce results on the problematic situation and the actors involved with it. Public policy is not static, it is modified according to the incidence of the actors with respect to it.

On the other hand, H. Lasswell [7] proposes to consider public policy as a scientific discipline and an applied social science [6;10]. Th. Dye states that a policy "is all that government actors decide to do or not do" (cited by [10, p. 92]).

The French researchers Y. Meny \& J.-C. Thoenig [10] argue that the study of public policies is nothing else but the study of the action of public authorities in society. A public policy is the work of the authorities of governmental public legitimacy. This, of course, encompasses several aspects, ranging from definition and selection to decision-making, administration and evaluation. That is to say, the aspects and non-committed acts of a public authority in relation to a problem or in a relevant sector of its competence, where it is presented in the form of a set of practices and rules emanating from one or more public actors. Finally, the authors conclude that a public policy must be able to be presented as a program of governmental action in a sector of the society or in a geographic space, of which it is attributed the following characteristics: content, program, normative orientation, factor of coercion and social competence.

Public policy can also be conceived as "the set of activities of government institutions, which act directly or through agents, are directed at influencing the lives of citizens" [18].

Another fundamental author in the study of public policies, points out [13, p. 37]:

It can be said that 'policies' deal with those spheres considered as 'public'. The idea of public policies presupposes the existence of a sphere or sphere of life that is not private or purely individual, but collective. The public understands that dimension of human activity that is believed to require governmental or social regulation or intervention, or at least the adoption of common measures.

Regarding cultural policies, it is undoubtedly necessary to address cultural rights first; since, compared to economic and social rights, much remains to be done about them. According to 
M. Aguilera [2], cultural rights are the least developed with respect to their scope, legal content and the possibility of having them respected.

These rights are treated as the "poor relatives" of human rights. It is difficult to find a Constitution in the world that contains a chapter that deals exhaustively with cultural rights, meaning the inclusion of artistic freedom, scientific and cultural communication, copyright, the right of access to culture, the right to identity and cultural difference, the right to the preservation of cultural heritage, the right to education, religion and expression [2].

Cultural rights should be considered as those fundamental rights that guarantee the free, equal and fraternal development of human beings in their different contexts of life, using this unique capacity that we have, among living beings, to be able to symbolize and create senses of life we can communicate to others [14].

There is a need to promote and strengthen cultural rights, to demand that they be taken seriously and that they be reflected in a specific policy on the subject. According to J. Symonides [19], cultural rights are a neglected category of human rights and therefore this can be reflected in a lack of consolidated cultural policies. Hence, many organizations, such as UNESCO, have been organizing to give them the corresponding impetus, such as Agenda 21 to name a few.

Cultural policies were defined at a meeting of UNESCO in 1967, such as practices and knowledge of administrative or financial management, intervention or non-intervention, which serve as a basis for state action to meet the cultural needs of the community [8].

For N. García Canclini [4], cultural policies are the set of interventions carried out by various agents, such as the state, non-governmental organizations or community groups, with the aim of orienting symbolic development and responding to the cultural needs of the population. Culture is considered the fourth pillar of sustainable development and is increasingly becoming the center of local politics, gaining relative weight and visibility through economic, social, urban or intrinsically cultural factors (identity, memory, creativity, critical knowledge, etc.), all linked to the concept of development.

In the second half of the 1980, the so-called "triangle" of sustainable development, described in the Brundtland Report [12] and the basic pillars of sustainable development (defined as that which satisfies the needs of the present without compromising the needs of future generations), which is currently used in local, national and global strategies as a model for analysis and public action oriented towards sustainable development.

Responding to this relatively recent phenomenon of the centrality of culture, there is a trend that stems from the work of J. Hawkes "The Fourth Pillar of Sustainability. Culture's Essential Role in Public Planning" [5] which advocates that culture square "the triangle of sustainable development, thus becoming the fourth pillar.

Agenda 21 of Culture, continues this idea in an international document that systematically addresses the importance of the relationship of culture, citizenship and sustainability. It is a document that expresses a series of commitments agreed upon and prioritized by cities and local governments, which acts as a "declaration of the cultural rights of citizens at the local level" [20, p. 41].

Also, Agenda 21 for culture was the first document of a global nature that sought to establish bases for a commitment of cities and local governments for cultural development, in which representatives of cities and local governments from around the world participated.

In this agenda, principles, commitments and recommendations were established that collaborate with the cultural development of local governments, with a total of 67 articles that contemplate the five dimensions: culture and human rights; culture and governance; culture, sustainability and territory; culture and social inclusion; and culture and economy.

\section{Assessment of cultural policies}

The evaluation of public policies is undoubtedly in recent years a central concern of governments, policy makers. Since, through this, it allows them to formulate policies with rationalization and coherences that give real solutions to the social problems that must face.

An important trend in the evaluation is the formative modality, oriented to three questions [16, p. 163]:

1) the extent to which the program is reaching the target population, 
2) the extent to which the presentation of services is consistent with the program design specifications, and

3) what resources have been spent or are being spent to carry out the program.

Y. Meny \& J.-C. Thoenig [10] point out that the evaluation consists of taking sides and giving up the evaluation is to leave aside the applicability of the social sciences, that is why it is necessary to front facing the problems, for this is it is necessary to have greater rigor in understanding the effects of public action, which implies three options for a given public policy. A first option is the reference values, these values can be objective expressed by a public policy, which will be selected by the analyst and, in the case of the descriptive attitude is not considered any value explicitly. As a second option are the impacts or observable effects on the ground, these impacts can be seen as transformations linked to government actions. Because all public policy has a theory of change, but also shows that a policy can be preventive, that is, it can prevent transformations voluntarily or authoritarian, we can also say that the impacts can mark the physical environment and finally, it is important to point out that the effects refer to the opinions and perceptions of the people, to their way of believing and thinking, more than anything, to the satisfaction of an intervention.

Thus, we can see that the evaluation function, carried out by citizens or analysts, constitutes the center of political debate in a society. Both J. Mejía [9] and the Spanish Evaluation Society [1] agree on three phases of policy evaluation:

The first is the ex ante or prior evaluation, which is carried out prior to the political project or program and is intended to provide the appropriate criteria for a qualitative decision to implement a policy, project or program; this type of evaluation is also known as feasibility, when it comes to a social policy should be considered its internal consistency and feasibility and not only economic profitability.

As a second, we have process evaluation, also called continuous evaluation, which is carried out during the implementation of the policy and seeks to detect the difficulties presented in programming, administration, control, etc., in order to make the corrections in a timely way and reduce the costs of inefficiency.
And as a third ex post exposure, also known as the terminal assessment, or the impact (considering that the impact assessment establishes the extent to which objectives were achieved and what their side effects are), focus on whether the expected results and the effects, both sought and collateral, attributed to the actions or instrumented projects were obtained.

The Agenda 21 of Culture, in its article 25, points out the need to "promote the implementation of forms of cultural impact assessment to consider, with a prescriptive nature, public or private initiatives that imply significant changes in the cultural life of the cities" [20, p. 10].

In the document "Culture: 21 actions. Selfevaluation guide", approved in the framework of the Bilbao Culture Summit (March 2015), establishes nine lines of action that are intended to serve as a basis for the level of development achieved by local governments regarding their cultural actions and programs:

- Patrimony, Diversity and Creativity;

- Culture and Education;

- Cultural Rights;

- Culture and Environment;

- Culture and Economy;

- Culture, Equity and Social Inclusion;

- Culture, Urban Planning and Public Space;

- Culture, Information and Knowledge;

- Governance of Culture.

For the purposes of this research the focus is on three of the axis: the first of these, cultural rights, are aimed to really be exercised or put into action, requires cultural policies that give special attention to the most vulnerable people and groups. The axis of culture and education, emphasized that municipal governments must approve local strategies that link education policy with cultural policy and, finally, the axis of equity and social inclusion, refers to the importance of looking for municipal strategies of the social sphere such as health, employment, welfare and social inclusion explicitly include cultural aspects as tools to combat all forms of discrimination. It is sought that the cultural institutions that receive public support carry out programs related to disadvantaged groups such as poverty, exclusion, among others. 
In 2009, the Spanish Federation of Municipalities and Provinces (FEMP3) developed a system of indicators to evaluate their cultural policies in the following areas:

- Culture as a factor of development Economic, Social and Territorial;

- Transversality of culture;

- Access to culture;

- Culture and citizen participation;

- Role of initiatives related to memory and innovation in the construction of local identity.

These themes make up a system of interdependencies and polysemy that makes their isolated and individual treatment difficult and even artificial.

Regarding to the theme of culture and citizen participation, the FEMP establishes three formulas of participation:

1) Use / assistance: refers to the behavior of use / practice and consumption / assistance that are given with respect to the local cultural offer;

2) Proposal: refers to how the local cultural offer is planned and configured;

3) Management: refers to how the local cultural offer is implemented, managed or produced.

And three types of "participant" agents:

1) Individuals: unorganized individual citizens;

2) Groups: associations, "non-formal" groups and voluntary structures, all linked to culture, in a broad sense;

3) Entities: public institutions (or with a significant public participation) or private (commercial entities or independent professionals) that intervene in the local cultural field.

\section{Context of the Secondary School No 9 of Topolobampo}

The port of Topolobampo, where the educational institution is located, it is part of the eight commons of the municipality of Ahome and according to the catalogue of localities of the Social Development Office from the federal government, in

\footnotetext{
${ }^{3}$ Federación Española de Municipalidades y Provincias (in Spanish).
}

Topolobampo there are 6,032 people, of which 3,045 are men and 2,987 are women.

In this locality, there are two secondary schools, Technical High School No 9, which is full shift and Mar de Cortez High School, which is an afternoon shift. Technical High School No 9 was founded in the year 1972 and in this one it is offer the technical specialties of fishing, refrigeration, processing and navigation. From its beginnings, the objective of this institution was the one to support to the families of low resources, offering them the service of masculine boarding. In the past school year 2015-2016, the school's enrolment was 280 students, of which 60 are inmate students, who participated mostly in the cultural program.

\section{RESULTS AND DISCUSSION}

\section{Background and design of the cultural program}

The cultural program "art for social development" in the municipality of Ahome is contemplated as one of the actions of the Municipal Development Plan (2014-2016). It was done considering the importance of establishing programs in the most vulnerable communities of the municipality. The Direction of the Municipal Institute of Art and Culture (IMAC) designed a program focused on a space with young people on risk situations, for this, technical secondary No 9 was chosen, located in the port of Topolobampo, municipality of Ahome.

According to the Principal's assistant of the secondary school the program was planned to carry out the cultural project with the young inmates because they consider that they are a group at risk with problems of family disintegration, underachievement, low income families, and some students with behavioral problems in their homes and previous schools. The program consisted in three free art workshops: theatre, music and painting, which were held from Monday to Thursday from 5:00 p. m. to 6:30 p. m. from March 15 to May 30, 2016.

It is important to mention the processes that were implemented for the hiring of teachers since there are elements that directly or indirectly affect the fulfillment or non-fulfillment of certain goals.

The planning of the program. According to one of the managers of the program, the biggest diffi- 
culty that the program had was the little budget to hire the instructors of the workshops and buy the necessary materials. On the one hand, the tabulation of some teachers who give art workshops in the municipality of Ahome, in some cases is inaccessible to the budget of municipal government programs, since some teachers are quoted in institutions where they guarantee economic perceptions that the municipality can't cover.

In other cases, they are artists who independently obtain significant dividends to which the municipal government on certain occasions, if not the majority, cannot fulfil.

It is important to mention that in the budget heading for this program, the municipal government emphasized that it had to include an instructor (guitar workshop) of another cultural program sponsored by tripartite resources (from the Federal Office of Culture, the Sinaloa Institute of Culture and the Municipality of Ahome), within the framework of programs approved by the Citizen Council for Municipal Cultural Develop- ment, requesting the instructor to develop part of their activities in the secondary school, since they only had a budget for two workshops.

The availability of instructors. The inconveniences of the availability of some artists were also curiously a factor that played against the hiring of the teachers who would give the workshop, most were developing activities in public or private institutions and some could only at certain times, contrary to the Idea that could prevail in the imaginary collective artists are more occupied when they are occupied.

The experience of the instructors. Because of the above, it is difficult for the council to demand certain conditions when there are no elements to reconcile the interests of the artists with those of the program itself, some of the teachers could find some experience in their field, but in others it was evident that it lacked an artistic pedagogy suitable for the goals that the city council itself had in mind (Table 1).

Table 1 - Biographical data of workshop facilitators

\begin{tabular}{|c|c|c|c|c|}
\hline \multirow[b]{2}{*}{ Workshop } & \multicolumn{4}{|c|}{ Facilitator } \\
\hline & Gender & Age & Training & Experience as an instructor \\
\hline Guitar & Masculine & 35 & Bachelor in music, specialty in classical music & 7 years as a guitar instructor \\
\hline Painting & Feminine & 18 & $\begin{array}{l}\text { High school and a course in painting in the } \\
\text { vocational school of art }\end{array}$ & No experience \\
\hline Theatre & Masculine & 40 & Self-learning actor in independent groups & $\begin{array}{l}5 \text { Years as an actor and } \\
\text { theatre director }\end{array}$ \\
\hline
\end{tabular}

Source: Own elaboration based on interviews

Material Resources for the workshops. The young participants in the workshops were given the necessary materials such as guitars and painting materials: paper shells, water paints and drawing pencils. In the case of the guitar workshop, the instructor took the guitars (purchased with the program budget mentioned above) and the guitar instructor was not provided with material.

\section{Diagnosis on the level of cultural consumption of participants in the cultural program}

The results obtained from the questionnaires applied at the beginning of the cultural program show that young inmates have limited contact with art and culture outside of what is shown to them in Secondary School.
First, to know the social and economic context of the students was considered essential for this research and the socio-demographic data obtained, show that the general socioeconomic level of these students is medium to low and the educational level of the parents is located between secondary and high school, a factor that has probably influenced the type of cultural consumption of students that will be shown later.

The second category of analysis was "use of leisure time", where it was observed that young people use their free time for various activities, among which exercise, internet use and TV. Below the results for the total of 48 students is shown (Figure 1). 


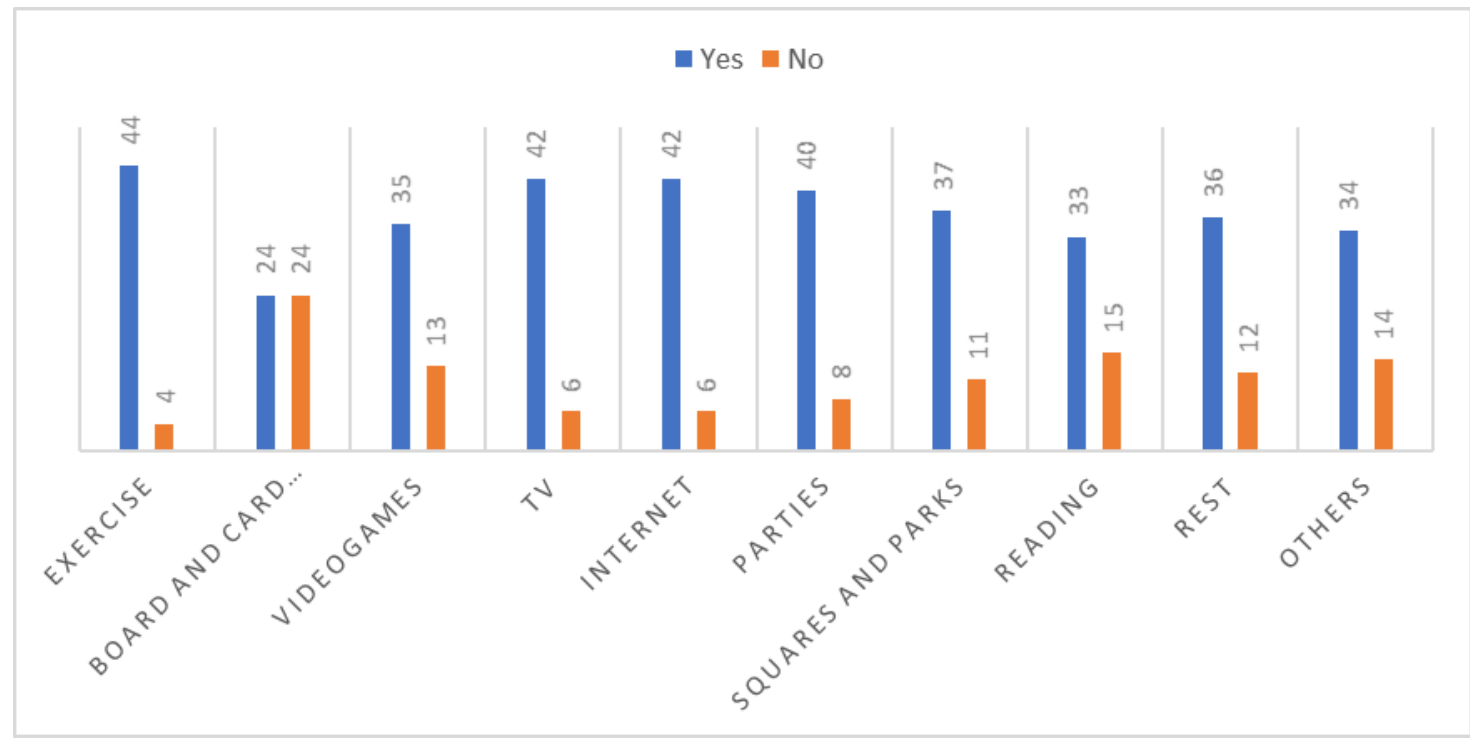

Figure 1 - Leisure time use

The third category of analysis focused on "cultural consumption", which was divided into four areas: cultural sites visited, attendance at festivities, attendance at cultural and artistic workshops, and appreciation of shows on public roads.
As for the cultural sites visited, the one that had the highest incidence was the Natural Park and the least visited is the House of Culture, even some of the young people surveyed did not know what the item "House of Culture" was referring to. The full graph is shown below (Figure 2).



Figure 2 - Cultural consumption

Regarding attendance at festivities, the fairs were the ones that received the highest percentage of attendance, since 39 of the 48 students surveyed mentioned that they have attended fairs on more than three occasions, also, civic festivities also have a significant positive percentage, reaching $96 \%$ attendance at least once (Figure 3 ).
Carnivals reach $52 \%$ in the assistance option on more than three occasions, while religious festivals and artistic festivals present similar results in the different options, having the first $75 \%$ attendance at least once and the second $73 \%$ in the same field. 




Figure 3 - Attendance to festivities

The section on "Participation in artistic and cultural workshops" shows that most of the young interns have never attended an art workshop, since only the drawing and music workshops had a greater impact on the participation of young people, are the only items that obtained a posi- tive percentage of participation of $58 \%$ and $62.5 \%$ respectively. The workshops in which most of the young people have not participated or have attended little are photography, literature, sculpture and theatre (Figure 4).

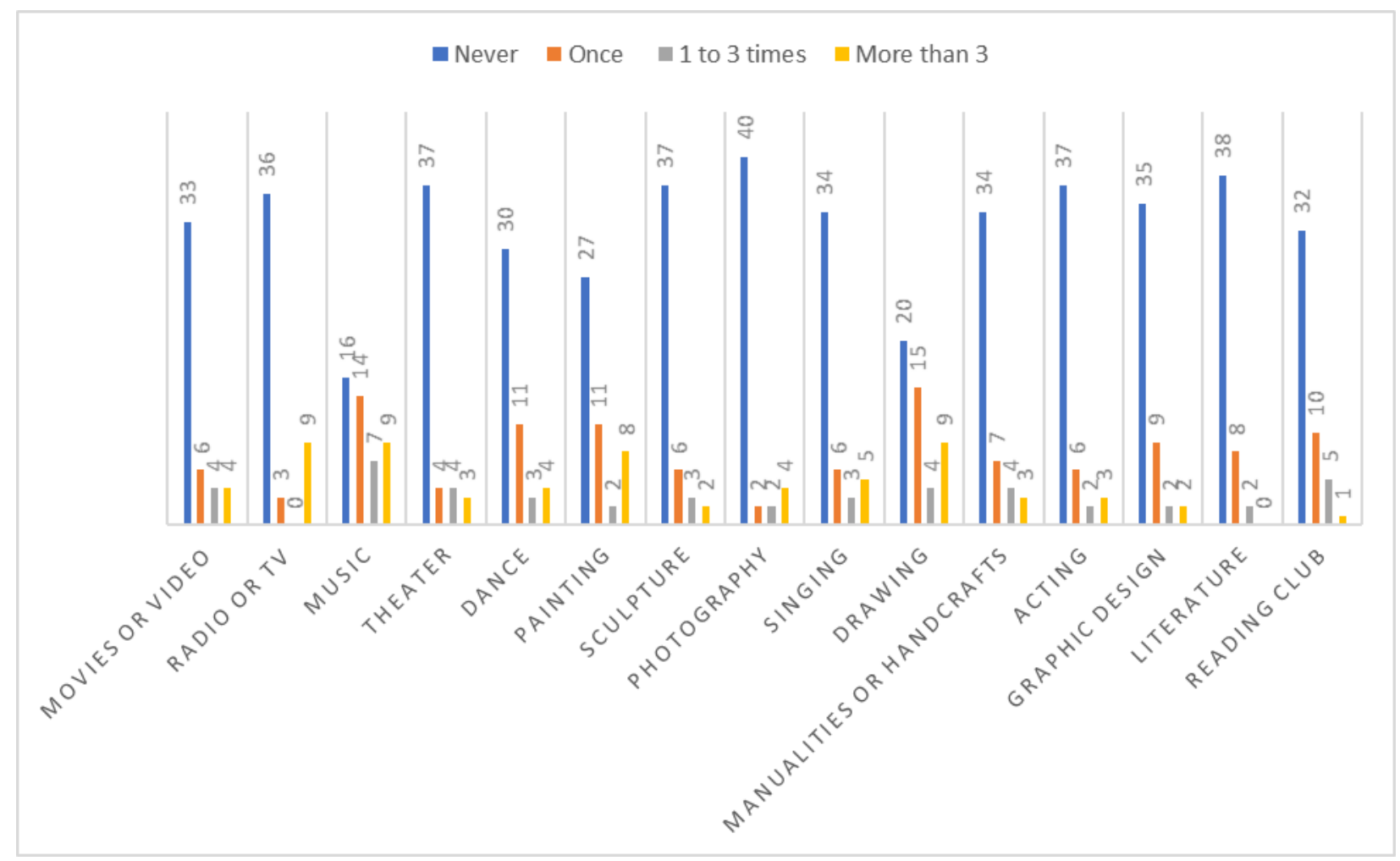

Figure 4 - Workshop participation

In the section on "Appreciation of public performances" the most attended kind of show is music, since 23 of the 48 students surveyed indicated that they have been to see this type of spec- tacles more than three times. The public spectacle less seen according to the results of the surveys is related to sculpture (Figure 5). 


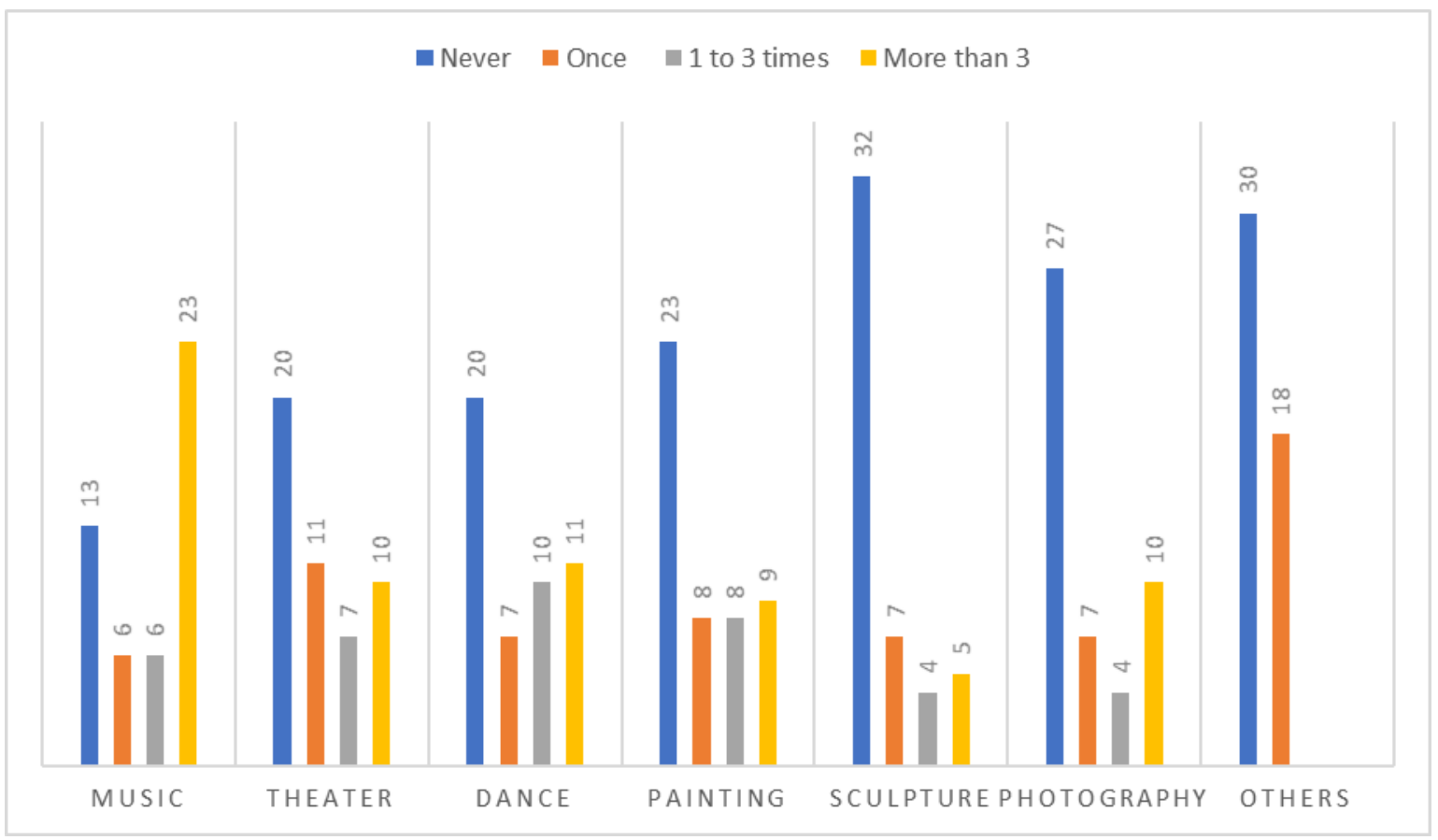

Figure 5 - Appreciation of public performances

According to the information above, it can be deduced that it is necessary to socialize, and to disseminate in a broader and sustained manner all that in the matter of culture has the municipality of Ahome. In addition, the diagnosis reflects the urgent need for cultural policies and programs that pay special attention to the most vulnerable people and groups, considering the tangible and intangible aspects of the promotion of art and culture. Likewise, the municipal government could articulate educational and cultural programs that value in an efficient and effective way the cultural resources and thus be able to contribute to a greater cultural consumption in the population.

\section{Development of the cultural program from the perspective of young participants and facilitators}

Initial Expectations. There was an inquiry about the expectations they had at the beginning of the cultural program. Most participants noted that the workshop they chose was the one that most attracted their attention. They expressed that " we expect to learn a lot about it", as the schedule seemed $100 \%$ adequate to develop in the evening shift after finishing their high school classes.

They were asked about expectations as to the workshop facilitator, responses varied. Most of the guitar pupils answered that they expected the teacher to be patient, followed by this charac- teristic are the qualities "to know how to explain" and "who knows a lot of guitar"; The painting students pointed out that what they expect from the workshop teacher is that "clear up all doubts", followed by the "be patient" option; and the theater students indicated that they expect "to be able to explain". From what is perceived, most of the interns have negative references to the performance of some professors who do not tempt them or who do not know how to explain, not of the cultural and artistic field, since they have not had previous experiences, but rather of the academic field.

Regarding the question "what do you expect from your classmates?", The students surveyed at the guitar workshop mentioned that the most important thing is for their peers to take care of the workshop materials; the painting students agreed that the three most important options are "respect", "pay attention" and "good behavior in class"; While theatre students emphasized respect as the most important option.

Guitar workshop development. For the participants of the guitar workshop was their first experience with this instrument, who expressed their desire to be able to rehearse more continuously and with a greater number of hours, however, the workshop lasted a short time (4 months), the lack of possibilities for the facilitator to attend was a factor that the students regretted, a situation that was not considered by the IMAC and which is, obviously, a serious failure because it 
generates a counterproductive emotive effect, the young people lamented that the teacher did not attend all the programmed classes for having other commitments, even though the facilitator expressed great interest in supporting the students, his personal and work agenda was an element that worked against the project of the workshop.

The intervention of the facilitator had an important emotional impact in the youngsters of the school, if it is considered as a success to facilitate the encounter with a musical instrument in an environment designed for it and with a person willing to transmit knowledge in relation to that instrument; this seemingly small experience could have further effects that a workshop hardly will be able to gauge or evaluate in its right measure, somehow the effects of art are temporally conditioned as a unique experience are incubated in the people and will become significant in their integral formation, the possibility of being attended from the elementary perspective of art that does not qualify or become an experience of a coercive nature will give the youth an idea of art very linked to freedom, a condition not given by other experiences of a formative nature.

The guitars were provided by the facilitator and they remained at the school while the workshop was held, so those who wished could practice outside the workshop hours during the afternoons they had available.

The commitment to the development of a skill linked to learning and master an instrument such as guitar is eminently personalized, so the strategy of designing a program in which students could continue practicing outside the workshop classes will surely have its repercussions in the future, since there were enough young people who applied to experiment and work with the guitar.

The facilitator, when interviewed, stated that his goal was to form a group and set up a small guitar recital, an objective that was not fulfilled since the students had no previous knowledge of the instrument and the guitars were insufficient for all the participants.

It was observed that the objectives and goals to be achieved by this program were not met with some of the expected products, however, the students expressed their interest to continue studying the instrument.
Where there was a coincidence was in the type of music they wanted to be taught, since the teacher indicated that although "the aim of the guitar workshop is to teach classical music, there will also be time for students to learn some pieces of music of their preference". The obvious thing is that the objective was not in accordance with the needs of the students. The teacher is a career musician, but the conditions for teaching classical music in a three-hour workshop a week seems difficult to achieve. As for the students surveyed, they mentioned that what they would most like to learn is classical music and ballads, with a $30 \%$ mention each, followed by the regional music option with a mention percentage of $20 \%$.

One of the objectives mentioned by the facilitator of the workshop is to form a guitar orchestra and present a recital at the end of the workshop, this is consistent with the expectation of the young inmates, as they mentioned that they hoped to learn songs, they were also interested in learning to read musical notes, an aspect that is addressed in the subject of solfeggio, which was the first to be given to the boys.

Development of the painting workshop. The painting workshop was the most constant, although the facilitator had little experience she was able to work with young people in a positive way. According to the testimony of the instructor the discipline was a difficult aspect to control, especially at the beginning of the workshop; she clarified to the students that this was the only workshop that was developed four days a week, therefore she managed to give greater continuity to development of the skills of the young participants. The instructor also attended in hours and days off schedule to meet needs or requests of young people.

One of the constants of the workshops was the polarity that existed between the instructors, some extremely dedicated to the dynamics and others at the opposite end without enough time to accompany them, besides this polarity manifested in the time that the teachers had, giving the ages of each of them, academic training and work experience, which opens a space to develop some working hypotheses that could focus on these differences and what are the effects in the development of cultural practices.

One aspect to emphasize in this sense, is the one related to the age and the work experience or the documentation of some facilitators, specifically the teacher of the painting workshop, a young 
woman of 18 years with little experience in the teaching, this disadvantage also becomes the element of analysis in the later development of workshops. To overcome this disadvantage, she gave the workshop much dedication that was an important factor in generating empathy with the students of the school and in obtaining better results.

A painting workshop that the teacher complemented with patience, tolerance, active listening and solidarity with the workshop, the conditions that can obviously be considered as a plus for her. She managed to teach some techniques that allowed the students to finished some good paintings, so this is a prove that, if the instructor can strength the self-confidence in the young, the achievements can also exceed their expectations.

The young people stated at the end of the workshop they were excited about having done three works of painting mostly on themes related to the port landscape and about characters (comic heroes) of their preference. They acknowledged that the teacher gave them the facilities to choose the subject.

Development of the theatre workshop. The theatre workshop had few participants, ranging from 4 to 6 students. In this workshop, it was much more difficult to get young people excited, the instructor did not attend in some occasions, which was discouraging the participation, it was not possible to mount any final work with the young people.

Even though the theatre workshop did not culminate in a final work, it is necessary to consider relevant aspects of it such as the young people who participated in this formative experience as actors that became involved in a creation process that was much more complex than other disciplines, since they developed the capacity to dialogue around a text that was redesigned according to their own experiences. And although it is true that the work did not end on stage, there were ephemeral staging on each occasion that they rehearsed in the hall.

Contribution of the workshops. In short, the students considered important the development of new artistic expression skills, activities that allowed them to occupy their time in a fun way and in turn allowed them to de-stress from all the daily work in school; $100 \%$ of the students expressed their interest that the workshops will continue the next cultural cycle and 50\% indi- cated that they would like to have other activities focused on sports.

Within the practices they carried out, the facilitators established affective links with the participants, related to one of the thematic axis about human rights, the possibility of coexistence and working on issues related to participatory assertive communication. This was mostly appreciated in the paint shop.

Undoubtedly, culture cannot be subject to the production of subjectivities about its value and its importance in the socio-economic and political machinery. The purpose of cultural discourse must be supported in the systematization of its planning and evaluation processes that communicate with certainty its achievements in the short, medium and long term.

\section{CONCLUSIONS}

The cultural program "Art for the social development" developed in the Secondary School No 9, was included, although of incipient form, in the axis of action scooped by the Agenda 21 of Culture, from the perspective of the social inclusion and the socialization of the cultural rights of young people. While it is true that elements that have not been evaluated for their transitive dimension, the inherent characteristic of the transformation processes, it can be deduced, according to testimonies issued by the participants to the workshops, that there is an optimistic indication to ensure that in the short time the young people who enter to one of the workshops, recognize the fact that they were taken into account by the municipality's program and, as it was expressed in their comments, the satisfaction of social inclusion and the feeling of belonging.

It was detected that some of the goals were not met, such as forming a group of strings to show the learning obtained in the guitar and theatre workshop, since only the drawings and paintings of the painting workshop were exhibited.

Also, it was observed the need for greater support by the government through the Office of Public Education and Culture of the State of Sinaloa towards the secondary school and the boarding school as it is a school with infrastructure problems and lack of staff to support students in the afternoons.

Likewise, other programs are required to prevent antisocial behavior in young people, since 
the main problem they have among them is excessive violence among peers, they are bullying as it is a game among them. Since they have new activities in which to invest their free time, the violence diminished, hence the importance of greater cultural, sporting and artistic activities, among others.

And even if the distinctive feature of culture is linked to the emotional and spiritual transformation of the subjects involved in cultural processes, it will be an exercise in the creativity of public policy to find indicators that point out the advantages that these transformations in subjects and in the community in general mean for the development of a community that persists in the search for guarantees of peaceful coexistence in a local development environment.

The social tool provided by the agenda 21 of culture from an integrative approach, gives guidelines to obtain doses of credibility that base the potential of the cultural process on social transformation.

Cultural politics and cultural programs in Ahome have at best a vision of culture from the aesthetic point of view that limits their scope and which is still in the process of becoming a vision that establish a systematic cultural development based on the Agenda 21, which prioritize in its cultural proposal, the factor of transversality of culture, access to culture, citizen participation, innovation in the construction of local identity and culture as a factor of economic, social development and territorial.

The contemporary era requires a greater emphasis on the need for cross-cutting approaches in the development of cultural programs and actions that allow the development of a public policy with connectivity characteristics towards sustainable development. In addition, they require determining the approach that generates cultural works, vision of pluralistic perspective, that attend the technological revolution and the culture.

In an odd world where the distorted industry of violence imposes the practices of social coexistence, it is imperative to provide cultural activities with tools that allow it to consolidate programs and actions at the local level that promotes the pacific coexistence and make better human beings in every aspect.

\section{REFERENCES}

1. Agencia Estatal de Evaluación de las Políticas Públicas y la Calidad de los Servicios. (2009). La función evaluadora: principios orientadores y directrices de actuación en la evaluación de políticas y programas. Retrieved from http://www.aeval.es/comun/pdf/actualidad/Funcion_evaluadora.pdf

2. Aguilera, M. (2008, March). Presente y Futuro de los Derechos Culturales. Crítica, 3(952). Retrieved from http://www.revista-critica.com/la-revista/editoriales/272-presente-y-futuro-de-losderechos-culturales

3. Federación Española de Municipios y Provincias. (2009). Guía para la evaluación de las políticas culturales locales. Retrieved from http://www.femp.es/files/120-18CampoFichero/Evaluacionpol\%C3\%ADticas.pdf

4. Garcia Canclini, N. (Ed.). (1987). Políticas culturales en América Latina. México: Grijalbo.

5. Hawkes, J. (2001). The fourth pillar of sustainability: Culture's essential role in public planning. Melbourne: Cultural Development Network.

6. Landau, M. (2000). El ámbito propio del análisis de políticas. In L. Aguilar (Ed.), El estudio de las políticas públicas (pp. 275-280). México: Porrúa.

7. Lasswell, H. (2000). La concepción emergente de las ciencias políticas. In L. Aguilar (Ed.), El estudio de las políticas públicas (pp. 105-118). México: Porrúa.

8. Lozano, U. M., \& Campillo, A. R. H. (1994). Políticas Culturales en Colombia. Discursos y Prácticas Institucionales. N. d.: Mena \& Herrera. 
9. Mejía, J. (2005). La evaluación como herramienta para una gestión pública orientada a resultados. La práctica de la evaluación en el ámbito público mexicano. Retrieved July 10, 2017, from http://www.empoderamiento.info/biblioteca/MVI_027.pdf

10. Meny, Y., Thoenig, J.-C. (1992). Las políticas públicas. Barcelona: Ariel.

11. Muller, P. (2002). Las políticas públicas. Administración y Desarrollo (Santafe de Bogotá), 38, 116119.

12. Organizaciones de las Naciones Unidas. (1987, August 4). Informe Brundtland. Retrieved from http://www.un.org/es/comun/docs/?symbol=A/42/427

13. Parsons, W., \& Aguilar, A. A. (2007). Políticas públicas: una introducción a la teoría y la práctica del análisis de políticas públicas. México: Facultad Latinoamericana de Ciencias Sociales, Sede Académica de México.

14. Prieto de Pedro, J. (2008). Derechos Culturales, el hijo pródigo de los Derechos Humanos. Crítica, 58(952), 19-23.

15. Quintero, V. M. (2001). Indicadores de gestión cultural. Retrieved from http://www.culturarecreacionydeporte.gov.co/portal/sites/default/files/6.\%20Indicadores\%2 0de\%20gestion\%20cultural.pdf

16. Rossi, P. H., Freeman, H. E. (1993). Evaluation: A Systematic Approach (5th ed.). Newbury Park: Sage.

17. Salazar Vargas, C. (2009). La evaluación y el análisis de políticas públicas. Opera, 9(9), 23-51.

18. Sanchez, M. P. (2005). Análisis de políticas públicas. Granada: Universidad de Granada.

19. Symonides, J. (2010). Derechos culturales: una categoría descuidada de derechos humanos. Sala de Penza, 5(124). Retrieve from http://www.saladeprensa.org/art952.htm

20. The Committee on culture of the world organization of United Cities and Local Governments. (2017). Agenda 21 de la Cultura. Retrieved from http://www.agenda21culture.net/documents/agenda-21-for-culture

21. Vargas Velasquez, A. (1999). Notas sobre el Estado y las políticas públicas. Santa Fe de Bogotá: Almudena Editores.

22. Velásquez Gavilanes, R. (2009). Hacia una nueva definición de concepto política pública. Desafíos, 20,149-187. 